\title{
ZRÓŻNICOWANIA REGIONALNE W UNII EUROPEJSKIEJ. WERYFIKACJA HIPOTEZY WILLIAMSONA
}

\begin{abstract}
Streszczenie
Celem artykułu jest weryfikacja aktualności tzw. hipotezy Williamsona, zakładającej krzywoliniową relację między wartością PKB per capita gospodarek narodowych a poziomem zróżnicowań regionalnych, które przyjmują kształt odwróconej litery U. Do weryfikacji tej hipotezy wykorzystano modele panelowe, a analizą objęto 22 kraje z 28 obecnie wchodzących w skład Unii Europejskiej. Pomiar regionalnych zróżnicowań został przeprowadzony wskaźnikiem będącym odchyleniem standardowym PKB per capita regionu względem kraju, podzielonym przez PKB na 1 mieszkańca w kraju, zaproponowanym przez Szörfi [Szörfi, 2007].

Analiza uzyskanych oszacowań modeli dla danych za okres lat 1995-2011 pozwoliła potwierdzić początkowy wzrost zróżnicowań wraz ze wzrostem poziomu zamożności gospodarki kraju (mierzony w PPS per capita), który po przekroczeniu pewnego poziomu zamożności kraju (tj. około 26400 PPS) wraz z dalszym wzrostem zamożności przeciętnie uległ obniżeniu. Testowane dwie specyfikacje modelu, tj. wersja z modelem kwadratowym oraz specyfikacja logarytmiczna, przede wszystkim wskazywały na narastający problem zróżnicowań regionalnych wraz ze wzrostem poziomu zamożności. Ich przewidywania istotnie różnily się po przekroczeniu progu około 30000 PPS, jednak to wersja kwadratowa cechowała się wyższym dopasowaniem modelu do danych.

Wnioski płynące z przeprowadzonej analizy dla Polski lub innych krajów europejskich ukazują nieodzowny problem zróżnicowań regionalnych, który pozostaje w istotnej relacji z poziomem zamożności gospodarki narodowej. Stąd też $\mathrm{w}$ świetle zaprezentowanych danych próby usilnego przeciwdziałania zróżnicowaniom regionalnym są trudne do uzyskania dla wielu krajów.
\end{abstract}

Słowa kluczowe: zróżnicowania regionalne, NUTS 2, krzywa Williamsona, hipoteza Williamsona, Unia Europejska

\section{REGIONAL DISPARITIES IN EUROPEAN UNION: THE WILLIAMSON HYPOTHESIS}

\section{Summary}

The aim of the paper is to verify the Williamson hypothesis that assumes a nonlinear relation between GDP per capita of national economies and the level of regional disparities, which take a form of an inverted U-shaped curve. In order to test the hypothesis, panel models were used to analyse data for 22 out of $28 \mathrm{EU}$ members. To calculate the level of regional inequalities, the author uses an indicator proposed by Szörfi [2007],

\footnotetext{
${ }^{1}$ Dr Jarosław M. Nazarczuk - Wydział Nauk Ekonomicznych, Uniwersytet Warmińsko-Mazurski w Olsztynie; e-mail: jaroslaw.nazarczuk@uwm.edu.pl.
} 
which is a standard deviation between GDP per capita in a region compared to the entire country, divided by the GDP per capita of the national economy.

The conducted analysis of the period of 1995-2011 has confirmed an initial increase in regional disparities accompanying the growth of national income level (in PPS per capita), which after reaching a certain level of GDP per capita (about 26,400 PPS) tends to decrease along with the further increase in income levels. The two tested specifications of the models (quadratic and logarithmic) mostly indicated the upward side of the curve, showing increasing disparities. Their predicted values diverged significantly for income levels, starting from ca. 30,000 PPS per capita. However, the quadratic specification of the model was better fitted to the data.

The findings from the conducted analysis for Poland and other EU countries indicate the important issue of regional diversity, so closely related to the national level of economic development. Therefore, the attempts of many EU countries to significantly reduce regional disparities are unsuccessful.

Key words: regional disparities, Williamson curve, NUTS 2, Williamson hypothesis, EU

\section{Wstęp}

Istotne zróżnicowanie przestrzeni społeczno-ekonomicznej determinuje możliwości wzrostu i rozwoju gospodarczego oraz w dużym stopniu warunkuje osiagnięty poziom rozwoju. Odmienne wyposażenie regionów w posiadane zasoby oraz złoża, położenie geograficzne i geopolityczne, klimat, bliskość skupisk ludności, a także lokalizacja zakładów przemysłowych, koncentracja działalności gospodarczej, jednostek badawczo-rozwojowych, dostępność infrastruktury technicznej, jakość zasobów pracy w dużym stopniu decydują o możliwościach rozwoju regionów [Bogdański, 2010, s. 278--279; Growing Regions..., 2007, s. 59-60; Korenik, 1999, s. 39-40; Nazarczuk, 2013, s. 24-26]. Na funkcjonowanie regionów oddziałuje również polityka makroekonomiczna państwa, jakość instytucji [Lizińska, 2012, s. 102-105], uchwalanego prawa, otwartość granic czy wreszcie procesy ponadregionalne, tj. globalizacja lub integracja [Strahl, 2006, s. 16-18].

Nierównomierne zdolności regionów do generowania wzrostu i rozwoju, a także zaszłości historyczne [Gawlikowska-Hueckel, 2002, s. 114] implikuja pojawianie się dysproporcji w rozwoju przestrzennym. Proces rozwoju jest zjawiskiem kumulacyjnym, co oznacza, że regiony, które w przeszłości dynamicznie rozwijały się, mają jednocześnie większy potencjał do generowania wzrostu w przyszłości. Stąd też w przestrzeni społeczno-ekonomicznej pojawiają się nierówności oraz procesy, które z jednej strony powodują utrwalanie przestrzennych wzorców rozwoju, z drugiej (najczęściej po przekroczeniu pewnego poziomu koncentracji/rozwoju, kiedy koszty aglomeracji są coraz wyższe) przyczyniają się do konwergencji poziomu zamożności wybranych obszarów [Nazarczuk, 2015, s. 132].

Celem artykułu jest weryfikacja aktualności hipotezy Williamsona, odnoszącej się do intensywności regionalnych zróżnicowań względem poziomu zamożności gospodarki krajowej, przyjmujacych kształt odwróconej litery U. Zgodnie z tą hipoteza, poziom zróżnicowań regionalnych narasta tylko do osiagnięcia przez kraj określonego poziomu zamożności, po przekroczeniu którego zróżnicowania regionalne maleja. Do weryfikacji tej hipotezy zostały wykorzystane modele panelowe, z kolei analizą objęto 22 kraje Unii Europejskiej w latach 1995-2011, posiadające co najmniej dwie jednostki NUTS 2.

Układ artykułu jest następujący. W części drugiej opisano uwarunkowania teoretyczne istnienia krzywej Williamsona. Część trzecia zawiera szczegółowy opis metod i danych 
wykorzystanych w badaniu. Wyniki uzyskanych analiz przedstawiono w rozdziale czwartym. Artykuł wieńczy podsumowanie, w którym odniesiono się także do innych wyników badań w tym zakresie.

\section{Zamożność gospodarki narodowej a poziom regionalnych zróżnicowań}

Badania nad istnieniem zależności między zamożnością gospodarki a poziomem zróżnicowań regionalnych zostały zaininicjowane przez J. G. Williamsona, który opierał się przede wszystkim na ustaleniach S. Kuznetsa w odniesieniu do krzywoliniowej relacji między poziomem osiaganego dochodu a zamożnością gospodarki narodowej [Kuznets, 1955, s. 4-6], jak również w pracach Myrdala [Myrdal, 1957] oraz Hirschmana [Hirschman, 1958]. Podstawą jego rozważań była konstatacja, zgodnie z która podczas przechodzenia z gospodarki agrarnej do przemysłowej początkowo rosną dochody wąskiej grupy społecznej (z uwagi na inwestycje w kapitał trwały), co powoduje wzrost zróżnicowań w poziomie dochodu społeczeństwa; z kolei, gdy gospodarka osiagnie wyższy poziom rozwoju i większa liczba pracowników przesunie się z sektora rolniczego do przemysłowego, wywoła to wzrost dochodów dużej liczby pracowników i w konsekwencji poziom zróżnicowań w wysokości osiąganych dochodów ulegnie zmniejszeniu [Lessmann, 2014, s. 35].

Podobnie jak Kuznets i Williamson, założył, że istnieje związek między zamożnością gospodarki a stopniem zróżnicowań regionalnych w poziomie dochodu. Jednak uwzględnił on dodatkowo aspekt przestrzenny analizy, opierając się na teorii polaryzacji regionalnej Myrdala oraz Hirschmana. Bazując na danych przekrojowych dla 24 krajów (oraz bardziej szczegółowej analizie szeregów danych dla wybranych gospodarek narodowych), dowiódł on istnienia krzywoliniowej zależności (o kształcie odwróconej litery U) między poziomem PKB per capita tych krajów a intensywnością regionalnych zróżnicowań w PKB na 1 mieszkańca [Williamson, 1965, s. 14-15].

Oznaczało to, że poziom międzyregionalnych zróżnicowań w PKB per capita dynamicznie zwiększał się wraz ze wzrostem zamożności gospodarki przy niskim poziomie dochodu na mieszkańca. Następnie, wraz ze wzrostem poziomu rozwoju kraju, tempo zróżnicowań regionalnych przybierało coraz mniej na sile, aby po przekroczeniu pewnego poziomu PKB na 1 mieszkańca kraju zróżnicowania regionalne zaczęły maleć wraz z dalszym rozwojem gospodarki narodowej [López-Bazo, Monastiriotis, Ramos, 2014, s. 116].

Przyczyn powyższej ścieżki ewolucji poziomu zróżnicowań regionalnych należy upatrywać przede wszystkim w przepływie czynników produkcji do ośrodków dobrze rozwiniętych [Geodecki, 2006, s. 87], a także zachodzących przemian strukturalnych i integracji gospodarki [Martínez-Galarraga, Rosés, Tirado, 2013, s. 3]. Na początkowym etapie rozwoju, gdy struktura gospodarki kraju rozwijającego się jest oparta głównie na sektorze pierwszym, w kraju istnieje niewiele biegunów wzrostu gromadzących w swoich granicach istotne zasoby kapitału oraz pracy. Postępujący proces industrializacji, opierający się na odkryciu nowych surowców naturalnych (rozmieszczonych nierównomiernie 
na terenie kraju), powoduje pojawianie się obszarów koncentracji działalności gospodarczej. Wykwalifikowani pracownicy oraz kapitał prywatny, będąc pod wpływem nowych możliwości zarobkowania, przemieszczają się do biegunów wzrostu, co prowadzi do łącznego wzrostu produktywności i w efekcie do wzrostu gospodarczego bieguna, a to wpływa na zwiększenie zróżnicowań międzyregionalnych [Davies, Hallet, 2002, s. 4].

Gdy gospodarka osiagnie wyższy poziom rozwoju, koszty czynników produkcji wzrosną oraz kiedy pojawią się niekorzyści skali związane z postępującym procesem aglomeracji, kapitał w postaci realizowanych inwestycji będzie miał tendencję do lokowania się w innych regionach (tzn. poza biegunami wzrostu), gdzie występują niższe koszty pracy czy nasycenie inwestycjami na pracownika [Szörfi, 2007, s. 102]. Będzie temu sprzyjać poprawa jakości sieci komunikacyjnej, jak również zmniejszenie kosztów transportu [Monastiriotis, 2014] i prowadzona polityka rozwoju [Lessmann, 2014, s. 35]. Dzięki wystapieniu efektów rozlewania (ang. spillover effects) możliwych przez takie kanały, jak: migracje, przepływy kapitału, handel zagraniczny czy polityka rozwoju [Barrios, Strobl, 2009, s. 576] będzie następować realokacja czynników produkcji $\mathrm{w}$ wymiarze sektorowym i przestrzennym, $\mathrm{w}$ tym na sąsiadujące obszary, prowadząc do konwergencji w poziomie regionalnego PKB na mieszkańca.

\section{Dane i metody badawcze}

Analiza poziomu zróżnicowań regionalnych została przeprowadzona dla 22 krajów UE28 w latach 1995-2011. Z badania wyłączono kraje posiadające mniej niż dwa regiony NUTS 2, dla których liczenie wskaźników zróżnicowań na tym poziomie agregacji było nieuzasadnione (tj.: Cypr, Estonię, Maltę, Litwę, Luksemburg, Łotwę).

Podstawowym źródłem informacji o regionach była baza danych EUROSTAT, z której zaczerpnięto informacje o PKB na 1 mieszkańca (w PPS per capita) w poszczególnych regionach i krajach Unii Europejskiej. W sumie udało się zgromadzić dane dla 22 krajów, zebrane w postaci panelu liczącego 350 obserwacji (niezbilansowanego z uwagi na nieliczne braki danych dla wybranych krajów w latach 1995-1999).

Do oceny poziomu zróżnicowań regionalnych wykorzystano wskaźnik zróżnicowania będący odchyleniem standardowym PKB per capita regionu względem kraju, podzielonym przez PKB na 1 mieszkańca w kraju [Szörfi, 2007, s. 107-108]:

$$
\text { ineq }_{i t}=\frac{\left[\sqrt{\frac{1}{N} \sum_{r=1}^{n}\left(p k b_{-} p c_{r t}-p k b_{-} p c_{i t}\right)^{2}}\right]}{p k b_{-} p c_{i t}},
$$

gdzie:

ine $q_{i t}$ - wskaźnik zróżnicowania w kraju $i$ w roku $t$, $p k b_{-} p c_{r t}-\mathrm{PKB}$ na 1 mieszkańca w regionie $r \mathrm{w}$ roku $t$, $p k b_{-} p c_{i t}-\mathrm{PKB}$ na 1 mieszkańca w kraju $i$ w roku $t$.

Jego zastosowanie miało na celu przede wszystkim uwypuklenie regionalnych różnic w poziomie dochodu. W wielu krajach obszary skupiające populację są również regio- 
nami o bardzo wysokiej koncentracji kapitału i produkcji (m.in. jako wynik uwarunkowań historycznych), stąd téz podobnie jak w pracy [Szörfi, 2007], zdecydowano się obliczyć współczynnik zróżnicowania bazujący nie na różnicach absolutnych w poziomie PKB per capita, a kwadratach tych różnic, co pozwoliło w większym stopniu oddać dystans między biegunami wzrostu a pozostałymi obszarami w kraju, determinujący rzeczywisty poziom zróżnicowania. Jest to zatem swego rodzaju współczynnik zróżnicowania i odchylenia standardowego ważony populacja, bowiem zamiast obliczania różnic między średnim poziomem PKB per capita kraju a jego wartością w regionie, wykorzystywane są wartości produktu dla poszczególnych regionów i ich gospodarek narodowych.

TABELA 1.

Statystyki opisowe danych wykorzystywanych w badaniu

\begin{tabular}{|c|c|c|c|c|c|}
\hline Zmienne & $\begin{array}{c}\text { Liczba ob- } \\
\text { serwacji }\end{array}$ & Średnia & $\begin{array}{c}\text { Odchylenie } \\
\text { standardowe }\end{array}$ & Min & Max \\
\hline$i d$ & 350 & - & - & 1 & 22 \\
rok & 350 & - & - & 1995 & 2011 \\
pkb_pc & 350 & 19824 & 7328,513 & 3900 & 36500 \\
pkb_pc2 & 350 & $4,47 \mathrm{E}+08$ & $2,87 \mathrm{E}+08$ & $1,52 \mathrm{E}+07$ & $1,33 \mathrm{E}+09$ \\
$i n e q$ & 350 & 0,257 & 0,130 & 0,006 & 0,758 \\
In_pkb_pc & 350 & 9,808 & 0,451 & 8,269 & 10,505 \\
\hline
\end{tabular}

Objaśnienia: $p k b \_p c-$ poziom PKB per capita, $p k p \_p c 2$ - poziom PKB per capita podniesiony do drugiej potęgi, ineq - współczynnik zróżnicowania regionalnego, ln_pkb_pc-logarytm naturalny z PKB per capita.

Źródło: opracowanie własne na podstawie danych EUROSTAT.

W celu weryfikacji krzywoliniowej zależności między poziomem zamożności gospodarki kraju a zróżnicowaniem PKB per capita regionów wykorzystano modele panelowe, które w odróżnieniu od wykorzystywanej w oryginalnej pracy Williamsona [Williamson, 1965] analizy przekrojowej, uwzględniają również zmianę poziomu zróżnicowań w czasie, co w przypadku arbitralnego wyboru okresu analizy (np. niezsynchronizowanego z cyklem koniunkturalnym kraju) dla danych przekrojowych mogłoby zaburzyć wartości uzyskanych wyników. Wobec tego wykorzystana procedura badawcza zakładała wykorzystanie danych panelowych do wery fikacji aktualności tzw. hipotezy Williamsona.

Podstawowym równaniem poddawanym testowaniu była ogólna postać modelu panelowego z zaimplementowaną krzywoliniową zależnością między poziomem zróżnicowań (ineqit) a poziomem PKB na 1 mieszkańca (gdpit). Początkowo testowano zarówno specyfikacje modelu $z$ efektami losowymi oraz ustalonymi, jednakże wyniki testu Hausmana dowiodły, że lepszą specyfikacją jest ta z efektami ustalonymi (co wskazuje na istotną rolę czynników specyficznych dla poszczególnych krajów w wyjaśnianiu zróżnicowań regionalnych), dlatego też w dalszej części pracy przedstawiono oszacowania modelu z efektami indywidualnymi o równaniu następującej postaci: 


$$
\text { ineq }_{i t}=\beta_{0}+\beta_{1} p k b_{-} p c_{i t}+\beta_{2} p k b_{-} p c_{i t}^{2}+a_{i}+\varepsilon_{i t} \text {, }
$$

gdzie:

ine $q_{i t}$ - wsółczynnik zróżnicowania regionalnego PKB per capita w kraju $i$ w roku $t$, $g d p_{i t}-\mathrm{PKB}$ per capita $\mathrm{w}$ kraju $i \mathrm{w}$ roku $t$ (w PPS per capita),

$a_{i}$ - wektor efektów indywidualnych,

$\varepsilon_{i t}-$ składnik losowy.

W przypadku, gdy hipoteza Williamsona jest prawdziwa, współczynnik $\beta_{2}$ powinien mieć znak ujemny, natomiast $\beta_{1}$ wartości dodatnie, co pozwoliłoby zaobserwować relację krzywoliniową między poziomem zamożności gospodarki krajowej a stopniem zróżnicowań regionalnych o kształcie odwróconej litery U. Dodatni znak przy $\beta_{1}$ oraz ujemny przy $\beta_{2}$ umożliwia zaobserwowanie charakterystycznego wygięcia po przekroczeniu pewnego poziomu zamożności.

Oprócz kwadratowej specyfikacji modelu zweryfikowano także inną postać modelu, uwzględniająca relację logarytmiczną między poziomem rozwoju gospodarki kraju a natężeniem zróżnicowań regionalnych. Stąd też, w opozycji do oryginalnej hipotezy Williamsona, sprawdzono również równanie postaci:

$$
\text { ineq }_{i t}=\beta_{0}+\beta_{1} \ln \_p k b \_p c_{i t}+a_{i}+\varepsilon_{i t},
$$

gdzie:

$\ln \_p k b \_p c_{i t}-\operatorname{logarytm}$ naturalny $\mathrm{PKB}$ per capita w kraju $i$ w roku $t$.

$\mathrm{Z}$ uwagi na pojawiający się problem heteroskedastyczności oraz autokorelację składnika losowego do oszacowania powyższych równań wykorzystano estymator panelowy ze skorygowanymi błędami standardowymi (ang. panel-corrected standard error, PCSE), który opiera się na regresji Praisa-Winsteina. Jest to jedna z dwóch najczęściej wykorzystywanych technik szacowania modeli panelowych z problemem autokorelacji i heteroskedastyczności (obok estymatora uogólnionej metody najmniejszych kwadratów, UMNK), [Dańska-Borsiak, 2011, s. 60]. Jak wskazuje Beck i Katz [Beck, Katz, 1995, s. 634], PCSE pozwala na uzyskanie dokładniejszych oszacowań błędów standardowych niż w przypadku estymatora UMNK. W celu uwzględnienia efektów indywidualnych wprowadzono do modelu serię zmiennych zerojedynkowych dla poszczególnych krajów objętych analizą.

\section{Zróżnicowania regionalne w Unii Europejskiej a krzywa o kształcie odwróconej litery $\mathbf{U}$}

Obserwowane zróżnicowanie regionalne w PKB na 1 mieszkańca (w PPS) w 22 krajach z grupy UE-28 w 2011 roku, uzyskane za pomocą równania (1), było relatywnie najwyższe w nowych krajach członkowskich, tj. w: Słowacji, Rumunii, Czechach, Węgrzech, Bułgarii oraz dodatkowo w Wielkiej Brytanii. Najnowszy członek Unii Europejskiej, tj. Chorwacja w badanym okresie odznaczała się najniższym zróżnicowaniem, stanowiąc istotny wyjątek od ogólnie obserwowanej tendencji, podobnie jak Słowenia 
(m.in. z uwagi na posiadanie tylko dwóch regionów NUTS 2 i relatywnie niewielkiej powierzchni ich terytorium). Względnie niskie zróżnicowanie było również cechą: Szwecji, Słowenii, Austrii czy Dani oraz innych krajów UE-15 (rysunek 1.).

\section{RYSUNEK 1.}

\section{Poziom zróżnicowań regionalnych a zamożność gospodarek narodowych w 2011 roku}

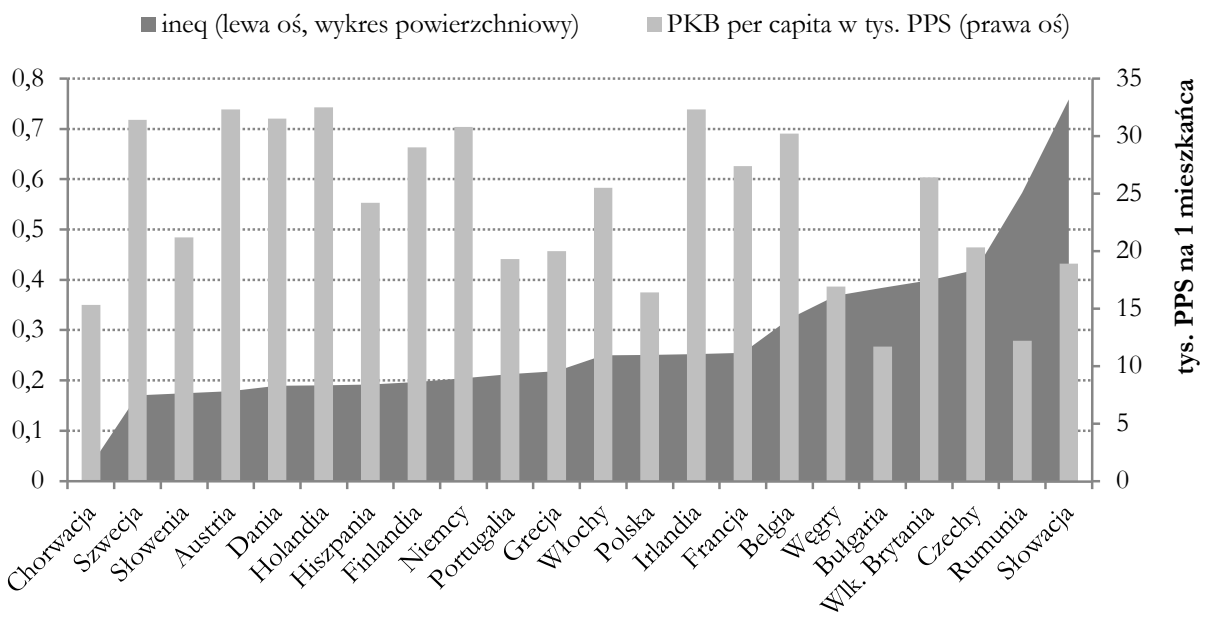

Objaśnienia: ineq - współczynnik zróżnicowania regionalnego PKB per capita. Źródło: opracowanie własne na podstawie danych EUROSTAT.

Bazując na powyższym wykresie, trudno jest jednoznacznie stwierdzić, które z gospodarek odznaczały się niższym zróżnicowaniem regionalnym. Jednak w większości przypadków to kraje zamożniejsze posiadały mniejszą intensywność różnic w poziomie dochodu między regionami, podczas gdy kraje biedniejsze - większe zróżnicowanie w wartości PKB per capita między regionami.

Dodatkowo, w latach 2000-2010 uległ zmniejszeniu poziom wskaźnika zróżnicowania w krajach, tj.: Austrii, Belgii, Finlandii, Niemczech, Irlandii, Włoszech, Hiszpanii i Szwecji. Były to kraje EU-15 cechujące się wyższym poziomem zamożności niż nowe kraje członkowskie o względnie niskim poziomie zróżnicowań. Z kolei silniejszy wzrost zróżnicowań przeciętnie był częściej widoczny w nowych krajach członkowskich (z wyłączeniem Chorwacji).

Analiza wyników estymowanych modeli dla poszczególnych krajów wykazała, że relacja między poziomem dochodu a wartością zróżnicowań jest krzywoliniowa. Uzyskane wartości przy współczynnikach $p k b \_p c$ oraz $p k b \_p c 2$ dla równania (2) odznaczały się wysokim poziomem istotności, podobnie jak test Walda łącznej istotności wszystkich zmiennych objaśniających. Dodatnia wartość współczynnika stojącego przy $p k b \_p c$ informowała, że poziom zróżnicowań narasta wraz ze wzrostem poziomu zamożności 
w kraju, a po przekroczeniu pewnego poziomu PKB per capita maleje (ujemny współczynnik przy $p k b \_p c 2$ ), (tabela 2.). W sumie równanie kwadratowe opisywało 99,1\% zmienności poziomu zróżnicowań regionalnych w 22 krajach Unii Europejskiej.

TABELA 2.

\section{Poziom PKB na 1 mieszkańca a zróżnicowania regionalne w Unii} Europejskiej

\begin{tabular}{|c|c|c|}
\hline Zmienne & Model kwadratowy & Model logarytmiczny \\
\hline pkb_pc & $0.00003^{* * *}$ & - \\
pkb_pc2 & $(0,000)$ & - \\
ln_pkb_pc & $-5.05 \mathrm{e}-10^{* * *}$ & $(0,000)$ \\
Stała & - & $0,12489^{* * *}$ \\
& & $(0,013)$ \\
R2 & $-0.15860^{* * *}$ & $-1,09296^{* * *}$ \\
(0,024) & $(0,137)$ \\
Test Walda łącznej istotno- & 0,991 & 0,978 \\
ści - wart. stat. $\chi^{2}$ & $44220,967^{* * *}$ & $24086,787^{* * *}$ \\
Liczba obserwacji & 350 & 350 \\
\hline
\end{tabular}

Objaśnienia: $p k b \_p c$ - poziom PKB per capita, $p k p_{\_} p c 2$ - poziom PKB per capita podniesiony do pierwszej potęgi, ln_pkb_pc-logarytm naturalny z PKB per capita. W nawiasach podano błędy standardowe. Poziomy istotności: ${ }^{*} \mathrm{p}<0,05,{ }^{* *} \mathrm{p}<0,01,{ }^{* * *} \mathrm{p}<0,001$.

Źródło: opracowanie własne.

Wyniki uzyskane dla logarytmicznej postaci modelu (równanie 3.) odznaczały się także wysokim poziomem istotności, jednak pojedyncza zmienna ln_pkb wyjaśniała niższy poziom zmienności zróżnicowań regionalnych w 22 krajach Unii Europejskiej $(97,8 \%)$. Oszacowany krzywoliniowy kształt zależności wskazywał na wyższy poziom zróżnicowań w bardziej zamożnych gospodarkach niż w przypadku specyfikacji kwadratowej. Jego bezpośrednia interpretacja ekonomiczna wykazała, że wobec wzrostu PKB per capita o 1\% poziom zróżnicowań regionalnych zwiększał się o 0,12489.

Względnie dobre dopasowanie logarytmicznej postaci modelu było związane z faktem uchwycenia przez nią przede wszystkim wzrostowego etapu krzywej Williamsona, dla której obie krzywe przebiegały w podobny sposób, a ich wartości nie różniły się istotnie od siebie. Dopiero od poziomu około 30000 PPS per capita przewidywane poziomy zróżnicowań między dwoma specyfikacjami faktycznie różniły się, wskazując: (1) dalszy spadek zróżnicowań w przypadku krzywej kwadratowej oraz (2) kontynuację wzrostu zróżnicowań dla specyfikacji logarytmicznej. 


\section{Podsumowanie}

Istnienie pewnych różnic w poziomie dochodu per capita jest nieodzownym elementem funkcjonowania gospodarek na poziomie regionalnym, na co wskazują zarówno pierwotne czynniki decydujące o nierównomiernym rozmieszczeniu czynników produkcji w przestrzeni, jak i będące wtórnym następstwem pierwotnych zróżnicowań, różnice w koncentracji podmiotów gospodarczych, ludności, specjalizacji wybranych obszarów itp. oraz dodatkowo jako zachodzących procesów w przestrzeni społeczno-ekonomicznej.

Przeprowadzona analiza z wykorzystaniem modeli panelowych potwierdziła aktualność tzw. hipotezy Williamsona w odniesieniu do relacji między zamożnościa gospodarek narodowych a poziomem zróżnicowań regionalnych w PKB per capita. Dla oszacowanej wersji kwadratowej modelu zróżnicowania regionalne przeciętnie narastały do wartości około 26400 PPS per capita, po czym poziom regionalnych zróżnicowań ulegał obniżeniu, wpisując się w kształt odwróconej litery U. Oszacowana wartość odpowiadała poziomowi dochodu na mieszkańca Wielkiej Brytanii z 2011 roku, Holandii z 2001 roku czy Austrii z 2003 roku.

Uzyskane oszacowania krzywej Williamsona wpisują się w wyniki innych badaczy, którzy analizowali relacje poziomu zróżnicowań i dochodu na 1 mieszkańca w regionach Unii Europejskiej czy USA [Amos, 1988; Amos, 1983; Barrios, Strobl, 2009; Szörfi, 2007]. W porównaniu z najbardziej zbliżonymi metodologicznie obliczeniami dla krajów Unii Europejskiej, opracowanymi przez B. Szörfi [Szörfi, 2007], średni poziom PKB per capita, od którego zmienia się kierunek zróżnicowań, uległ zwiększeniu z 22800 do 26400 PPS. Jednak do tych wartości należy podchodzić z ostrożnością, z uwagi na inny okres analizy, ilość krajów oraz metodę estymacji modeli.

W świetle uzyskanych danych wnioski płynące dla krajów europejskich są dość proste. Poziom zróżnicowań regionalnych pozostaje w istotnym związku z poziomem zamożności gospodarek narodowych. Stąd też próby zniwelowania lub istotnego obniżenia poziomu zróżnicowań regionalnych w średnim, a nawet długim okresie, są dla wielu krajów bardzo trudne do osiagnięcia. W przypadku Polski (tj. kraju cechującego się poziomem PKB per capita 16400 PPS) sa one w zasadzie jednokierunkowe. Implikują dalszy wzrost zróżnicowań regionalnych w średnim okresie. Realizowana obecnie w kraju polityka rozwoju oparta na polaryzacyjno-dyfuzyjnym modelu wpisuje się w uzyskane wyniki analizy, stymulując rozwój obszarów wybranych terytorialnie.

Jednak należy mieć świadomość, że występowanie prawidłowości zgodnych z hipotezą Williamsona jest niekiedy uwarunkowane: okresem analizy, przyjętą metodą oceny poziomu zróżnicowań regionalnych, a przede wszystkim zakresem geograficznym i poziomem agregacji danych wykorzystanych do badania. Dodatkowo, szacowane indywidualne krzywe Williamsona nie zawsze pozwalają jednoznacznie wypowiedzieć się na temat występowania opisywanej prawidłowości we wszystkich krajach Unii Europejskiej [por. Kusideł, 2013, s. 151]. Z kolei niektórzy badawcze identyfikuja, poza wystąpieniem zależności o kształcie odwróconej litery U między poziomem dochodu a poziomem zróżnicowań regionalnych, także potencjalny, kolejny etap wzrostowy występujacy bezpośrednio po zakończeniu pełnego cyklu zgodnego z hipotezą Williamsona 
[Lessmann, 2014, s. 42]. Stąd do jednoznacznego przekładania wniosków na praktykę gospodarczą trzeba podchodzić z pewną rezerwa.

Niedawne badanie, przeprowadzone na próbie 31 krajów OECD w latach 19702010, wskazało, że nierówności regionalne w długim okresie przyczyniają się do ograniczenia tempa wzrostu gospodarczego [Cingano, 2014, s. 28], dlatego też istnieje ciagła potrzeba monitorowania skali zróżnicowań regionalnych i w konsekwencji realizacji prób jego obniżenia.

\section{Literatura}

Amos O. M. Jr. 1983 The Relationship between Regional Income Inequality, Personal Income Inequality, and Development, ,Regional Science Perspectives”, vol. 13, no. 2.

Amos O. M. Jr. 1988 Unbalanced Regional Growth and Regional Income Inequality in the Latter

Stages of Development, ,Regional Science and Urban Economics”, vol. 18, no. 4., DOI: 10.1016/0166-0462(88)90026-9.

Barrios S., Strobl E. 2009 The Dynamics of Regional Inequalities, „Regional Science and Urban Economics", vol. 39, no. 5, DOI: 10.1016/j.regsciurbeco.2009.03.008.

Beck N., Katz J. N. 1995 What to Do (and Not to Do) with Time-Series Cross-Section Data, „American Political Science Review”, vol. 89, no. 03, DOI: 10.2307/2082979.

Bogdański M. 2010 Urban Determinants of Polarisation of Economic Development in Poland, „Olsztyn Economic Journal”, 5(2), DOI: 10.2478/v10021-010-0021-3.

Cingano F. 2014 Trends in Income Inequality and its Impact on Economic Growth, „OECD Social, Employment and Migration Working Papers”, no. 163, OECD Publishing, DOI: $10.1787 / 5$ jxrjncwxv6j-en.

Dańska-Borsiak B. 2011 Dynamiczne modele panelowe $w$ badaniach ekonomicznych, Wydawnictwo Uniwersytetu Lódzkiego, Łódź.

Davies S., Hallet M. 2002 Interactions between National and Regional Development, „HWWA Discussion Paper", no. 207.

Gawlikowska-Hueckel K. 2002 Procesy rozwoju regionalnego w Unï Europejskiej: konwergencja czy polaryzacja?, Wydawnictwo Uniwersytetu Gdańskiego, Gdańsk.

Geodecki T. 2006 Procesy konwergencji i polaryzacji w regionach Unii Europejskiej, „Zeszyty Naukowe Akademii Ekonomicznej w Krakowie”, nr 714.

Growing Regions, Growing Europe, 2007, Komisja Europejska, Luksemburg.

Hirschman A. O. 1958 The Strategy of Economic Development, Yale University Press, New Haven.

Korenik S. 1999 Rozwój regionu ekonomicznnego na praykkładz̨ie Dolnego Ślaska, „,Prace Naukowe Akademii Ekonomicznej we Wrocławiu. Seria: Monografie i Opracowania”, nr 131.

Kusideł E. 2013 Konwergencja gospodarcza w Polsce i jej znaczenie w osiaganiu celów polityki spójności, Wydawnictwo Uniwersytetu Lódzkiego, Lódź.

Kuznets S. 1955 Economic Growth and Income Inequality, „The American Economic Review", vol. 45, no. 1. 
Lessmann Ch. 2014 Spatial Inequality and Development - Is There an Inverted-U Relationship?, „Journal of Development Economics”, vol. 106, DOI: 10.1016/j.jdeveco. 2013.08.011.

Lizińska W. 2012 Klimat inwestycyjny jako czynnik bezpośrednich inwestycï zagranicznych, Wydawnictwo Uniwersytetu Warmińsko-Mazurskiego, Olsztyn.

López-Bazo E., Monastiriotis V., Ramos R. 2014 Spatial Inequalities and Economic Growth, „Spatial Economic Analysis”, vol. 9, no. 2, DOI: 10.1080/17421772.2014. 904615.

Martínez-Galarraga J., Rosés J. R., Tirado D. 2013 The Long-Term Patterns of Regional Income Inequality in Spain, 1860-2000, „Regional Studies”, August 2014, DOI: 10.1080/ 00343404.2013 .783692 .

Metody oceny rozwoju regionalnego 2006, D. Strahl (red.), Wydawnictwo Akademii Ekonomicznej im. Oskara Langego, Wrocław.

Monastiriotis V. 2014 Regional Growth and National Development: Transition in Central and Eastern Europe and the Regional Kurnets Curve in the East and the West, ,Spatial Economic Analysis", vol. 9, no. 2, DOI: 10.1080/17421772.2014.891156.

Myrdal G. 1957 The Drift Towards Regional Economic Inequalities in a Country, [in:] Economic Theory and Underdeveloped Regions, Harper \& Row, New York.

Nazarczuk J. M. 2013 Potencjat rozwojowy a aktywność inwestycyjna województw i podregionów Polski, Wydawnictwo Uniwersytetu Warmińsko-Mazurskiego, Olsztyn.

Nazarczuk J. M. 2015 Regional distance: the concept and empirical evidence from Poland, „Bulletin of Geography. Socio-economic Series”, no. 28, DOI: 10.1515/bog-2015-0020.

Szörfi B. 2007 Development and Regional Disparities - Testing the Williamson Curve Hypothesis in the European Union, „Focus”, no. 2.

Williamson J. G. 1965 Regional Inequality and the Process of National Development: A Description of the Patterns, „Economic Development and Cultural Change”, vol. 13, no. 4, DOI: $10.1086 / 450136$. 